\title{
Cultural Approach in Bilingual Training of International Students
}

\author{
Olga Khudobina ${ }^{1}$, Igor Fedulov², and Ekaterina Bondarenko ${ }^{3}$ \\ ${ }^{1}$ Department of foreign languages, Yugra State University, 16, Chekhova str., Khanty-Mansiysk, 628012, Russia \\ ${ }^{2}$ Department of history, philosophy and law, Yugra State University, 16, Chekhova str., Khanty-Mansiysk, 628012, Russia \\ ${ }^{3}$ Department of Basic and Clinical Biochemistry, Volgograd State Medical University, 1, Pavshikh Bortsov Sq., Volgograd, 400131, \\ Russia
}

\begin{abstract}
Bilingual training of international students is a vocational training of learners with the use of two languages - English/French and Russian where the latter is a foreign language. The cultural approach regards culture as a key component integrated in science classes and humanities as well as language ones, aimed at cultural awareness that the students will heighten through constant reflection about the Self and the Others in order to develop linguistic and intercultural competences and facilitate a better understanding of a broader range of vocational contexts (scientific, social, clinical, political etc.) that the students are exposed to. Questionnaires, oral and written reports, classroom observations and interviews were used to collect the data. The findings show student's positive perceptions of the cultural approach and highlight the value of explicitly considering a cultural component in content courses. Most students found the cultural approach as an effective way of facilitating intercultural communication and understanding.
\end{abstract}

\section{Introduction}

Intensive processes of international integration cover a wide range of spheres as well as the educational one. The Volgograd region has become an important experimental area for different international educational projects, including teaching a great number of international students in the framework of bilingual education. In this scheme bilingual education is considered as instruction aimed at acquiring expertise with the use of two languages - English/French and Russian. Several different kinds of bilingual programs are available to international students, and the value of bilingualism is seen by them differently. These programs differ in the degree to which they use the languages. Speaking of training of international students, the most popular programs are two kinds of bilingual instruction implemented through so-called "immersion" and "transitional" method. An immersion program is designed so that the use of English is a temporary phase of studying at the preparatory faculty to attain a proper level of Russian proficiency and continue training in the foreign language. In contrast, in transitional programs instruction is given in two languages: in English over the first three years and in Russian in the senior years. Thus, in both programs Russian is used as a foreign language.

Student's success in bilingual programs is undoubtedly due to a number of factors - institutional, pedagogical, cultural, national, religious, personal, etc. [1]. These include the students' ability to learn a foreign language (to develop successfully four aspects of linguistic competence), to perform well in both languages, to form close partnerships and positive attitudes toward native speakers and their culture, etc. [2]. This calls for a laborious search for the most effective methods and completely new principles underlying the interaction of these factors.

\section{Problem statement}

A fundamentally new communicative situation in the learning process makes it necessary to rethink some of the main issues of vocational training of international students. A person brought up within the framework of another culture has a different world view; his mentality is of a different nature and has its own cultural guidelines and values. During the learning process, an international student is not only exposed to a set of new concepts, determined by the chosen profession, but, above all, he faces a completely different mentality of people around him. A different mentality is expressed by a different structure of knowledge about the surrounding world, other behavior codes, norms and values. There are many most important concepts of Russian culture that sometimes do not even have any equivalent in the native language of the international student. This "cultural dissonance" hinders successful communication in the learning process, leads to slow progress in socialization of international students and, ultimately, negatively affects the learning itself. Therefore, it is quite obvious that bilingual training needs specific teaching strategies focusing on the "dialogue of mentalities" as a soft immersion into a positive learning environment, taking into account the student's national and cultural characteristics.

Moreover, students engaged in instruction under "transitional" programs, come to Russia without any

\footnotetext{
Corresponding author: ugrasu@ugrasu.ru
} 
knowledge of the Russian language; so they experience problems in communicating not only at the university, but also in many other public places, which is due to their inability to speak Russian and to perceive Russian speech aurally. Practice shows that students do not learn Russian rapidly and that lack of progress has a negative effect on the quality of their life. In "immersion" groups, as practice shows, at the stage of receiving instruction in Russian, linguistic competence is still limited in all aspects of language proficiency while communicative competence is not formed yet, but the educational system requires instruction in this language, highlighting the role of both communicative and cognitive functions of the language. Thus, the situation becomes even more frustrating, highly probably leading to low academic performance in general.

\section{Research questions}

Having studied the scientific literature and practical problems, we put forward a hypothesis that instruction of international students will become more effective if cultural approach is integrated with content teaching of subjects such as science courses and humanities. Numerous scholars have proposed that language and culture be regarded as "two sides of the same coin" [3-7]. They have demonstrated that language is a part of culture, and culture is a part of language. It means that through the study of other languages, students gain knowledge and understanding of the cultures that use that language. Thus, what we need is teaching strategy which represents professional, linguistic and cultural contents holistically so as to help students to develop both linguistic and cultural tools as well as their desire to use them in intercultural communication with Russian language speakers in order to gain expertise in particular, and enrich the professional culture as a whole.

Figure 1 displays the way the content, the languages (Russian/English) and cultures are fused through the bilingual holistic approach.

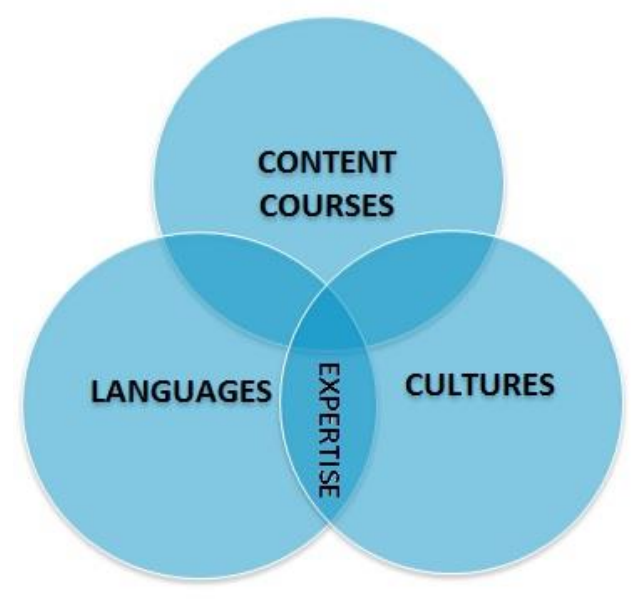

Fig. 1. Content, language and culture integration.

The idea of integrating science content and language learning, the approach, regarding culture as a key component, comes alongside the potential development of literacy in the classroom. Meyer et al. assert that progression along the knowledge pathway towards deeper subject understanding requires "strengthening the connection between the conceptual continuum and communication continuum"[8]. Researches such as Fang, Lame, and Pringle as well as Whittaker and Acevedo remind us of the importance of a greater mastery of subject-specific literacies and highlight the potential for multiple literacies developed at content classes [9-10]. In different studies, the teacher is a scientist who understands the need to promote intercultural understanding associated with scientific literacy in bilingual contexts, especially at a level where subject courses have their own cultures and ways of communicating and seeing the world [11-13]. According to Howells et al., cultural awareness is "the selfexamination and in-depth exploration of one's own cultural and professional background"[6]. The vision of culture is supported by Holiday who claims that "the concept of culture can be connected to activities where there is social interaction and cohesive behavior of representatives of different cultures"[14]. Dasli points out, that in foreign language teaching a cross-cultural approach seeks ways to understand the Other by learning one's own culture, enhancing the development of linguistic, socio-cultural and other competences [7].

Thus, we consider cultural approach as a core component integrated in science lessons and humanities as well as language classes, aimed at cultural awareness that the students will heighten through constant reflection about the Self and the Other in order to develop multilingual and multicultural competences and facilitate a better understanding of a broader range of vocational contexts (scientific, social, clinical, political etc.) that the students are exposed to. With regards to multicultural and multilingual competences, the Common European Framework of Reference for Languages defines them as 'the ability to use languages for the purposes of communication and to take part in intercultural interaction, where a person, viewed as a social agent has proficiency, of varying degrees, in several languages and experience of several cultures' [15]. It is noteworthy that we are talking about multicultural competence, since English and French are generally well-mastered languages for the students, but they are not mothertongues for Indian, Malaysian, Arabic and other students. Edgar Garzon-Diaz notes that 'science learners forge their identities by seeking membership of a community that they want to be part of by sharing the same language, codes and values [5]. These values shape what they do and empower them with rights and responsibilities that reflect their mutual understanding of the world'.

\section{Objective of the study}

The aims of the work were twofold. We first sought to understand the cultural and linguistic backgrounds, experiences and difficulties of all the international students enrolled in the first year program at the Volgograd State Medical University. We then sought to investigate the impact of cultural approach on these 
students' cultural awareness and their ability to switch with ease and adapt in the unfamiliar social-cultural environment, accurately read social and cultural cues and form a positive attitude toward Russian culture and its members in order to gain professional knowledge, values, attitudes, and enrich their professional culture.

Thus, the fundamental approach to bilingual education is the cultural approach of educating and training future specialists of high professional culture and expertise, combining the basics of vocational, national and world culture, aimed at self-development and further accumulation of cultural values. According to D.S. Likhachev, "Culture of a mankind is not going ahead by moving in space and time, but by accumulating values. The more values we see, the more sophisticated and keen our perception of other cultures becomes"[16].

To implement the cultural approach, it is necessary to fulfill a number of principles:

- principle of 'openness' implies willingness to develop an awareness of unfamiliar culture and willingness to interact with native speakers of the foreign language culture and to form a positive attitude toward the target culture and its members. It is the interaction of cultures that can lend facts and ideas that are peculiar to one culture to another culture in order to broaden the mind of representatives of both cultures and to understand better their own. L.N. Luzina states that "the mind then and only then the mind, when it is not identical with the flow of its own thought, when it is able to see the flow from the outside. When it is possible to see another 'me' in oneself' $[1,199]$. Without this 'me', without another culture, one can not feel one's own uniqueness. Folk proverb says that "everything is known in comparison";

- principle of 'parity of cultures' implies the equality of all peoples and cultures, their great importance and value, possession of equal rights in the world community. Strict observance of this principle is indispensable, since any evaluative judgments in relation to the attitudes and values of another culture as 'right' or 'wrong' will lead students to ethnocentric and nationalistic positions;

- cognitive principle develops the willingness to acquire knowledge of the foreign language culture and willingness to perceive social, cultural, religious and other cross-cultural differences and similarities. Implementation of the principle provides learners with knowledge of norms, beliefs, customs, attitudes, values and experiences that foster intercultural understanding of the behavior of individuals in different contexts.

An example of implementing this approach can be a class on random events within a "Theory of Probability" course. At the lesson, after considering the typology of events, theorems of addition and multiplication of probabilities, it is advisable to refer to examples from classical Russian literature. The works of Alexander Sergeyevich Pushkin, for example, speak on the theme of randomness repeatedly and mysteriously. Incredible as it may seem, poetic reflection of some properties of random events can be seen in the poem "Winter evening":

Наша ветхая лачужка (Our wretched little cottage) И печальна и темна. (Is gloomy and dark)
Что же ты, моя старушка, (Why do уои sit all silent)

Приумолкла у окна? (Hugging the window, old gran?)

Или бури завываньем (Has the howling of the storm)

$T$ bl, мой друг, утомлена,(Wearied you, at last, dear friend?)

Или дремлешь под жужжанье (Or are you dozing fitfully)

Своего веретена? (Under the spinning wheel's humming?)

In the poem, the random event 'Что же ты, моя старушка, Приумолкла у окна?' (Why do уои sit all silent?) consists of two exclusive random events. They are: 'Has the howling of the storm?' or 'Are you dozing fitfully under the spinning wheel's humming?'

International students perfectly know the greatest Russian poet and go on getting acquainted with his work, expanding the range of their background and cultural knowledge. The approach significantly activates the students' cognitive activity, increasing the effectiveness of both the learning process and the socio-cultural and linguistic adaptation of students.

- principle of 'comparative analysis' suggests that teachers should develop cross-cultural awareness by focusing on cross-cultural similarities and differences. The principle should permeate the entire structure of the educational process: learning, teaching and assessment. It determines the discovery of 'parallels' and 'points of contact' between cultures;

- principle of 'emotionality' implies immersion into the emotional sphere during the learning process. Teaching should be conducted not only on cognitive, but also on affective levels. Savignon and Sysoyev assert that effective intercultural communication comes about only when learners assume their role both as open-minded representatives of their first language community and as subjects engaged in a dialogue of cultures [17]. Only in a dialogue of cultures students are able to question the normalcy of the behavior acceptable in their native culture, or even radically change their behavior. Confrontation with one's own Self can cause serious emotional experiences leading to a desire to reconsider one's behavior and values, overcome the stereotypes and come to constructive communication. To achieve this goal, different elements of intercultural training are used. These are games, discussions, ethnographic interviews, problem-based situations, role plays, dialogues etc.

The principle of comparative analysis was implemented at Russian History classes. At the class consideration was given to some historical events occurring simultaneously in Russia and in students' native countries. For example, in the 7th century a huge array of Slavic tribes divided into three main branches: the eastern, western and southern Slavs. When covering this important event, it is necessary to focus students from Islamic countries on the fact that Islam originated in Arabia in the same century. Speaking about the formation of the Old Russian state in the 9th century, one can simply mention that feudal disunity of Islamic caliphate took place at the same time, which led to the final disintegration of this superpower of the medieval world. Representatives of the 
African continent may be interested in the fact that the process of forming Kievan Russia coincided with the formation of strong states succeeding each other on the territory of modern Chad. In 1957, the Soviet Union launched the world's first artificial earth satellite into space. And it was the year when the colonial independence of Malaysia was proclaimed, which enabled it to become an independent state.

A certain similarity of historical events is also observed when considering the genesis and initial development of such world religions as Christianity and Islam. Thus, the process of separation of Christians into Orthodox and Catholics took place in the IV-XI centuries. In Islam, the separation of Sunnites and Shiites from each other occurred after the death of Muhammad (in 632) in the same VII century. Taking into account the differences of some historical processes, teachers should focus on essential similarities - on the need to achieve intercultural understanding between representatives of different confessions and cultures for the preservation of human civilization.

As a result, students become more active, find out little known facts from the history of their native country that occurred synchronously with the events of Russian history, thereby achieving the goal of the cultural approach - through the course content to learn the set of values peculiar to Russian culture.

\section{Research methods}

This study followed the four-step cycle suggested by Sagor [18]. Each cycle allows the teacher-researcher to discover critical knowledge and insight required to improve their teaching strategies and help students achieve their learning goals. In the first stage there were determined the main objectives of the study. In the second stage, there were stated the most appropriate methods, tools and strategies to achieve the goals. The third stage involved the classroom intervention and data gathering. The study was implemented over one academic year. Pedagogical intervention took place in four groups of students in the transitional program (40 students) and four groups of students in immersion programs (40 students). Pedagogical experiment was conducted at subject classes where content, language and culture were fused through the bilingual holistic approach. However, in this study we consider only the cultural component of the bilingual holistic approach due to the limited size of the article.

The data in the present study were gathered via questionnaires and interviews complementing each other. Eighty students were given a pre-questionnaire to elicit information about students' age, previous experiences of foreign language learning, difficulties they encounter, studying in Russia (see Appendix 1 for pre-questionnaire) and reasons for getting education in Russia. First-year students were aged 18-20, which was almost the same age group. Most students were those from India (91,25\%), three students from Malaysia and four students from Kenya. Thus, we could easily state that the sample was homogeneous. The majority of students $(80 \%)$ were male. The interview showed that in India male population exceeded female population and what was noteworthy for our study, people in India used to stereotype Russia as a rather dangerous country for girls. All the participants asserted that they lived in multilingual and multicultural countries but they felt partially assimilated in those cultures almost to the point of not differentiating them from their own. Indian students speak different languages such as Hindi, Tamil, Bengal and others. But their school instruction was in English. From there, they have never experienced learning in a foreign language. As for their encounters representatives of Russian culture, they were mostly accidental and skin-deep. They saw Russian tourists in India and some students wanted to take a picture of blond Russian children. Very few students have visited other countries, mostly for travelling for a short period of time. Some students agreed that they had certain negative stereotypes about Russia and still retain them.

Student's responses to what difficulties they face studying in Russia revolved around five main clusters that are displayed in Table 1. It should be noted that each student could distinguish not only one but several difficulties that he/she experiences while studying in Russia, so the percentages indicated in Table1 are not summed up, but precisely and clearly demonstrate the number of students who have marked the corresponding problem.

Table 1. Students' responses to the question: What difficulties do you face studying in Russia?

\begin{tabular}{|c|c|c|c|c|}
\hline \multirow{2}{*}{ Item } & \multicolumn{2}{|c|}{$\begin{array}{c}\text { Transitional } \\
\text { program }\end{array}$} & \multicolumn{2}{c|}{$\begin{array}{c}\text { Immersion } \\
\text { program }\end{array}$} \\
\cline { 2 - 5 } & $\begin{array}{c}\text { Number } \\
\text { of } \\
\text { students }\end{array}$ & Percent & $\begin{array}{c}\text { Number } \\
\text { of } \\
\text { students }\end{array}$ & Percent \\
\hline $\begin{array}{c}\text { Russian } \\
\text { language }\end{array}$ & 20 & 50 & 28 & 70 \\
\hline $\begin{array}{c}\text { Russian } \\
\text { culture }\end{array}$ & 29 & 72.5 & 18 & 40 \\
\hline $\begin{array}{c}\text { System of } \\
\text { education }\end{array}$ & 16 & 40 & 23 & 57.5 \\
\hline $\begin{array}{c}\text { Every day } \\
\text { problems }\end{array}$ & 15 & 37.5 & 10 & 25 \\
\hline Climate & 7 & 17.5 & 5 & 12.5 \\
\hline
\end{tabular}

The majority of respondents $(83 \%)$ decided to get a doctor's profession in Russia, believing that it was here that they could master this prestigious profession at the best level, marking Russian higher education as one of the best. At the same time, many students believe that language difficulties hinder the learning process. However, students of different bilingual programs define the language difficulties in different ways. Students in the "immersion" groups reported the difficulties of listening, speaking and writing in Russian, at the lectures and practical classes. This indicates lack of progress in Russian proficiency and the need for extra work on the development of students' linguistic competences in the foreign language, that of the skills of speech behavior in certain learning situations. In "transition" groups, students study in the first three years in a well-mastered language and do not experience the acute problem of learning in it, but they exhibit notable difficulties communicating in public places: in shops, at the chemist's, in the polyclinics, 
in hostels, in transport, in the streets and at the university, when dealing with personnel who do not know English. Students complain about language isolation and stress, which they experience in different life situations. Moreover, students know that in the third year active clinical practice begins at the patient's bed, when professional dialogue comes first, so slow mastery of the Russian language causes students great fears and creates a sense of insurmountable obstacles.

As for the cultural component, due to the difficulties associated with the peculiarities of adjusting to Russian culture, students of "transitional" groups put forward the difficulties of understanding and accepting the cultural contexts: beliefs and traditions, values and knowledge, behaviors, manners, holidays etc as well as the problems of studying the Russian language. Being representatives of another culture, students may not be able to resist the acquired stereotypes. And this harms both the personality of the student and intercultural relations. Even the absence of student's canteen in the hostel was attributed by them as one of the peculiarities of Russian culture, thereby determining culture as the most important phenomenon that permeated all spheres of human life activities.

Some remarkable statements were noted from the interviews and questionnaires such as the following:

In India they said to me that Russians were very rude and were not tolerant to strangers. It might be true, because they unwilling to talk to us. I asked many people to help me find an address but they felt scared.

Russian people speak in a low voice and I always want to ask them to speak loudly and many of them do not speak English at all!

Teachers at the University want us to call them by their names but the latter are very difficult and in our culture it is not respectful to address a teacher by his/her name.

The style of life of Russian people is totally different from ours. They are always in a hurry; they are constantly busy at work. They do not have many holidays and days off to spend it with their families. Maybe they do not value their families as we do?!

Russian people have different holidays and unfortunately do not have festivals like Indians. They do not like to have fun.

Russian girls are too fashion-centered. They wear short dresses and make- up. I want them to wear sari and make-up only at festivals.

In "immersion" groups, so-called 'cultural problems' come third, after problems associated with different learning situations. This is because students who have lived in Russia for a year have undergone partial adaptation to life and culture, they have mastered the necessary level of the Russian language, allowing them to communicate in simple typical situations, requiring simple information exchange within familiar topics and activities but they still experience problems learning in Russian. In the cluster 'system of education' students of both programs describe the difficulties of learning a large volume of complex theoretical material, they complain about long duration of classes, unfamiliar system of assessments, etc.

The obtained data confirm the relevance of implementing the cultural approach in bilingual training of international students. It becomes clear that incentives for acquiring knowledge for the students are professional motives, but language barriers are obstacles in their educational progress. Moreover, most of students' stereotypes and prejudices were based on their unawareness of Russian culture.

\section{Findings}

Finally, in the fought stage, there was a reflection on the data obtained, and based on this reflection future research actions were planned.

Students' perceptions of the pedagogical intervention were mostly positive. Most (85\%) reported that dealing with the Russian language and cultural content in their subject courses was 'very good' and they felt motivated to use the language even outside the university. The results are shown in table 2 .

Table 2. Student's responses to the question: "Do you think the integration of cultural approach in your content classes was ...?"

\begin{tabular}{|l|c|c|}
\hline Item & $\begin{array}{c}\text { Number of students } \\
\text { (total number is 80) }\end{array}$ & $\begin{array}{c}\text { Percentage } \\
(\%)\end{array}$ \\
\hline Very good & 68 & 85 \\
\hline Good & 10 & 12.5 \\
\hline Bad & 1 & 1.25 \\
\hline Really bad & 1 & 1.25 \\
\hline
\end{tabular}

Students felt that the integration of content, language and culture was innovative and challenging. They found it easier to use the language and develop their cultural awareness while focusing on subject content that really interested them. The teachers felt the project to have been of value to them and recommended using it in future content classes, whereas only two students responded negatively (see Table 2). Students' comments were as follows:

I feel more confident using Russian, I learned poems written by Russian poets by heart in my physics classes and tried to determine the physical law, described in the poem. It was so amazing! Pushkin is my favourite Russian poet! Now I read Russian poems every day and learn more about Russian culture.

Classes were so dynamic! Working in groups we tried to match Russian proverbs with the graphs of functions in Mathematics. I have never heard these proverbs before but they are very wise and teach us to live and be smart.

We learnt more about history of our countries. It was really interesting to find out that our country was granted independence at the date when the Soviet Union launched the world's first satellite into space. It is nice that the teacher knows the history of my country and that is he respects me and my culture. (Malaysian student)

The teacher was so close to us. We can talk to him about different things and I told him at last that when we were shaking head from left to right it meant that the things he explained to us 'were clear' but it was not symbolized 'not'. So it was not necessary to repeat the explanation. (Indian student)

The teacher was friendly, humorous and patient and that encouraged me to speak out and express my ideas about the problem, we had to solve at our physics class. 
I used to stereotype Russian people as unfriendly and rude, but while studying in the framework of cultural approach, my views changed. I found that most of them are polite, humorous and easy going. They cherish their families and I want to make friends with Russians.

Analysis of the students' reflections has shown that the cultural approach helps students to review their behavior and values, overcome their stereotypes and socio-cultural barriers that hinder the process of acceptance of professional values and knowledge. Moreover it confirms that establishing a positive class atmosphere is a key for engaging students in the proposed activities. When there is a favourable atmosphere in class, students not only feel free to participate in the suggested activities but also feel they can create and propose new ideas and activities, verbalize their fears and stereotypes, and see that they are not alone in their fears and difficulties. It means that a content teacher becomes a 'mediator between cultures', a person who has to complete a lot of different tasks. They should provide optimal challenges in the learning process and rich sources of stimulation for the students to perform well, to increase their communicative skills, to develop a true appreciation for culture worldwide and a positive attitude toward the unfamiliar culture and its members. Thus, teachers should adopt the role of supportive facilitators rather than authority figures and seek to develop a rapport with students.

Students' interviews suggested that cultural project encouraged them to develop positive attitudes toward and feelings about the target language speakers and their culture. This result is noteworthy since students reported an increasing interest in using Russian in their future life (Table 3).

Table 3. Student's responses to the question: In what situation, if any, do you see yourself using the Russian language in the future? (Note: after receiving a diploma).

\begin{tabular}{|l|c|c|}
\hline Item & $\begin{array}{c}\text { Number of } \\
\text { students }\end{array}$ & $\begin{array}{c}\text { Percentage } \\
(\%)\end{array}$ \\
\hline $\begin{array}{l}\text { Want to visit Russia } \\
\text { with my future family }\end{array}$ & 36 & 45 \\
\hline $\begin{array}{l}\text { Want to communicate } \\
\text { with Russian friends if } \\
\text { there are any }\end{array}$ & 22 & 27.5 \\
\hline $\begin{array}{l}\text { Want to help Russian } \\
\text { people in my country }\end{array}$ & 17 & 21.25 \\
\hline Will not use at all & 5 & 6.25 \\
\hline
\end{tabular}

\section{Conclusion}

An analysis of surveys, final reports and reflection interviews suggests that students develop intercultural awareness and gain insight into the values of Russian culture, explore similarities and differences between cultures. These findings indicate that the cultural approach reduces the distance between learners and Russian language speakers in a very natural way and promotes openness toward individuals of other cultures and an increased desire to interact with them. Through intercultural communication, students become aware of stereotypes they have accepted as true before coming to Russia and actively confront them, discarding or revising them. Moreover, the results confirmed that the majority of students considered the cultural approach as an effective way of fostering intercultural communication and understanding.

Content teachers remark that students of experimental groups increased their communicative abilities, lower their level of anxiety, became more active in expressing their ideas, feelings, attitudes, desires and needs and became highly motivated which resulted in better academic performance in contrast to control group students. The main role should be given to Russian teachers, since linguistic difficulties stem from language learning problems, although the effectiveness of learning process can be achieved only by means of close teamwork of language and content subject teachers. Additionally, content subject teachers may find it interesting to highlight the role of culture at their classes.

Further studies should include more students from a variety of courses (second, third year students etc.) in order to provide a complete picture. However, the cultural approach should be modified through inclusion of cultural elements in the content of clinical courses, for example, by taking into account the specifics of infectious and dermatological diseases in the students' countries; ways of treating patients using international modern and traditional for students' countries methods of treatment - yoga and naturopathy for Indian students, acupuncture and reflexology for students from China and other eastern countries.

The sample was relatively homogeneous (mostly Indian students). Thus, with more heterogeneous samples one might also investigate how social and cultural backgrounds affect the way learners comprehend and interpret unfamiliar cultures and what factors might influence students' interpretations of the cultures.

\section{References}

1. M.N. Pevzner, A.G. Shirin, Bilingual education in the era of globalization (Yaroslav-the-Wise Novgorod State University, Veliky Novgorod, 2010)

2. O.F. Khudobina, Psychological barriers and factors of their overcoming in bilingual education at university level (on the example of training of international medical students) (Volgograd State Medical University, Volgograd, (2013)

3. Su. Ya-Chen, Educational Studies 34(4), 377-398 (2008)

4. M. Byram, Language Awareness 21(1-2), 5-13 (2012)

5. E. Garzon-Diaz, International Journal of Bilingual Education and Bilingualism 1-18 (2018)

6. S. Howells, G.M. Barton, M. F. Westerveld, International Journal of Speech-Language Pathology 1-13 (2016)

7. M. Dasli, Pedagogy, Culture \& Society 19(1), 21-39 (2011) 
8. O. Meyer, D. Coyle, A. Halbach, K. Schuck, and T. Ting, Language, Culture and Curriculum 28(1), 4157 (2015)

9. Z. Fang, L. Lame, R. Pringle, Thousand Oaks, Language and literacy in inquiry-based science classrooms, grades (CA: Corwin, 2010)

10. R. Whittaker, C. Acevedo, Estodios Sobre Educación 31, 37-55 (2016)

11. N. Barranco, F. J. Sanz, M. T. Calderón, A. I. Alario, Estudios Sobre Educación 31, 159-175 (2016)

12. F. Genesee, E Hamayan, CLIL in Context: Practical guidance for educators. (Cambridge: Cambridge University Press, 2016)

13. V. Nargund-Joshi, N. Bautista, The Science Teacher 83 (4), 24-30, (2016)

A. Holiday, Applied Linguistics 20(2), 237-264, (1999)

14. Council of Europe, Common European Framework of Reference for Languages: Learning, Teaching, Assessment (Cambridge: Cambridge University Press, 2001)

15. D.S. Likhachev, Letters on the good and beautiful, (Alpina Publisher, (2017)

16. S.J. Savignon, P.V. Sysoyev, Modern Language Journal 86(4), 508-524, (2002)

17. R. Sagor, Thousand Oaks, The action research guidebook: A four-step process for educators and school teams (CA: Corwin, 2005)

\section{Appendix 1. Pre-questionnaire for the first year students.}

Instruction: Please write down your responses to the following questions.

1. What is your age?

2. What is your gender? (Male/female)

3 . What is your country of birth?

4. Have you ever visited or lived in another country? If so, list the purpose and length of your visit.

5 . What is your first language?

6. Do you speak any foreign language/s? If so, please list the language/s and explain the experience you have with each language (e.g., studied for 2 years in high school).

7. What is your level of competency of Russian? (minimal, functional, proficient)

8. Have you ever been to Russia?

9. Have you ever interacted with Russian-speaking people in your country? If so, please provide the following information:

Type of interaction

Length/frequency of interaction

10. Did you have any cultural stereotypes and prejudices before coming to Russia?

Please list any of them.

11. What difficulties do your face studying in Russia?
12. Most people acknowledge that some differences exist among the various cultures of the world. When you think of cultural differences, what comes to mind?

13. Think of a time in which you interacted with Russianspeaking people. Please describe the experience in at least 100-150 words - how you met the person or people, what occurred in the interaction and how you felt about the experience.

14. Why did you choose Russia as a country for getting your future profession? 